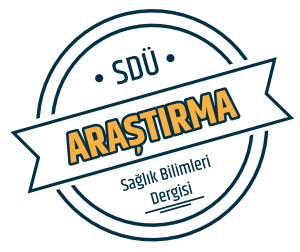

Sdü Sağlık Bilimleri Enstitüsü Dergisi / Cilt 9 Sayı 2 / 2018

Opinions of Adıyaman University Dental Faculty Students on Interactive Anatomy Education

\title{
Adıyaman Üniversitesi Diş Hekimliği Fakültesi Öğrencilerinin İnteraktif Anatomi Eğitimine İlişkin Görüşleri
}

\author{
Zümrüt Doğan ${ }^{1}$, Öznur Uludağ ${ }^{2}$, Sibel Ateşoğlu ${ }^{1}$, Fatih Üçkardeş̧${ }^{3}$, Ali Aydin ${ }^{1}$ \\ ${ }^{1}$ Department of Anatomy, Adiyaman University Faculty of Medicine, Adiyaman, Turkey. \\ ${ }^{2}$ Department of Anaesthesiology and Reanimation, Adiyaman University Faculty of Medicine Adiyaman, Turkey. \\ ${ }^{3}$ Department of Byoistatistic, Adiyaman University Faculty of Medicine, Adiyaman, Turkey.
}

\begin{abstract}
Objective: In recent years, dentistry has determined its characteristic values in scientific sense. Anatomy lectures is availabe in the first year of dentistry education as in all branches of health care related field. The evaluation and understanding of students' perspectives in anatomy education is of great importance in the development of anatomy education and teaching methods. In this study, it is aimed to evaluate the thoughts about anatomy education of first year students of Adiyaman University Faculty of Dentistry and to find out the contribution that they have made to the interactive anatomy learning through team work.
\end{abstract}

Material-Method: 60 students $(n=60)$ who receive anatomy lecture in the first semester of Adiyaman University Faculty of Dentistry in the academic year of 2016-2017 were included in the study. Data were obtained by using a feedback questionnaire consisting of 29 closed-ended questions. The questionnaires have been prepared to be answered with a scale of 5-point likert. The data were analyzed using the IBM SPSS statistics package program.

Results: It is estimated that the students used lecture notes for theoretical part and textbook for practical part mostly. Satisfaction levels of $88.3 \%$ and $85 \%$ were detected for theoretical part and practical courses respectively. $71.7 \%$ of the students completed project assignments within 1-3 weeks. $70.0 \%$ of the students included in the study reported that they found this practice contributed to like anatomy courses. While $91.7 \%$ of the students emphasized that the homeworks they have contributed to their anatomy learning, $73.4 \%$ of the students gave up the idea of 'working anatomy and understanding difficult'.

Conclusions: We believe that the data obtained will be useful in developing educational alternatives related to anatomy, in overcoming existing deficiencies and in providing students with assignments and active participation in education. In addition, we have also pointed out that the education given in dentistry faculties can reach better points by applying feedback questionnaires in anatomy education which needs a lot of time and effort.

Keywords: Anatomy Education, Faculty of Dentistry, Feedback

DOI: $10.22312 /$ sdusbed.44075

Müracaat tarihi: 04.07 .2018

Kabul tarihi: 06.08 .2018

\section{Özet}

Amaç: Son yıllarda diş hekimliği bilimsel anlamda karakteristik değerlerini belirlemiştir. Sağlık alanında eğitim veren tüm branşlarda olduğu gibi Diş Hekimliği Fakültelerinde de öğretim programının ilk yılında anatomi eğitimi verilmektedir. Anatomi eğitiminde öğrencilerin bakış açılarının değerlendirilmesi ve anlaşılması, anatomi eğitimi ve öğretim yöntemlerinin geliştirilmesinde büyük önem taşımaktadır. $\mathrm{Bu}$ çalışmada Adıyaman Üniversitesi Diş Hekimliği Fakültesinde öğrenim gören 1. sınıf öğrencilerinin anatomi eğitimi hakkındaki düşüncelerinin değerlendirmesi ayrıca takım çalışmaları ile interaktif eğitimin anatominin öğrenilmesine sağladı̆̆ katkıların ortaya çıkarılması amaçlanmaktadır.

Materyal-Method: Çalışmaya 2016-2017 eğitim-öğretim yılında Adıyaman Üniversitesi Diş Hekimliği Fakültesine ait 1. sınıfta anatomi eğitimi alan toplam 60 öğrenci $(n=60)$ dahil edildi. Veriler 29 kapalı uçlu sorudan oluşan bir anket formu kullanılarak geri bildirim yöntemiyle elde edildi. Anket soruları 5'li Likert ölçeği ile cevaplandırılacak şekilde hazırlandı. Elde edilen veriler IBM SPSS paket programı ile analiz edildi.

Bulgular: Öğrencilerin, anatominin teorik kısmını çalışırken en çok ders notlarından, pratik kısmını çalışırken en çok ders kitabından faydalandıkları tespit edildi. Aldıkları anatomi eğitiminin teorik kısmı için \%88,3 ve pratik kısmı için \%85,0 memnuniyet düzeyleri olduğu belirlendi. Öğrencilerin \%71,7'si 1-3 hafta içerisinde proje ödevlerini bitirmiştir. Çalışmaya dâhil olan öğrencilerin \%70,0'i bu uygulamanın anatomi derslerini sevmelerine katkı sağladığını belirtmiştir. Öğrencilerin \%91,7'si hazırladıkları ödevlerin anatomi öğrenmelerine katkıda bulunduğunu vurgularken \%73,4' ̈̈ 'anatomi çalışmak ve anlamak zordur' düşüncesinden vazgeçmişlerdir.

Sonuç: Elde edilen verilerin anatomi ile ilişkili eğitim alternatifleri geliştirmesinde, mevcut eksikliklerin giderilmesinde ve verilen proje ödevleri ile öğrencilerin eğitime aktif katılmasının sağlanmasıyla anatominin daha etkin öğrenilmesinde yararlı olacağını düşünmekteyiz. Ayrıca diş hekimliği fakültelerinde de ciddi bir zaman ve emek harcanan anatomi eğitiminde geri bildirim anketleri uygulanarak verilen eğitimlerin daha iyi noktalara gelebileceğine de dikkat çekmiş olmaktayiz.

Anahtar kelimeler: Anatomi Eğitimi, Diş Hekimliği Fakültesi, Geri Bildirim

Yazışma Adresi / Corresponding: Zumrut Dogan, Adiyaman University Faculty of Medicine Department of Anatomy, 02100, Adiyaman, Turkey. Tel: $05379709250 / 04162233800-1485$

Fax: +90 2164741256

E-mail: byozumrut@yahoo.com, byoozumrut@gmail.com 


\section{Introduction}

Dental science, being a part of general medical education for the past several hundred years, has established itself as an institutional and resident by making use of the tradition of general medical disciplines. In the following periods, dentistry as a special and unique medical discipline determined the scientific parameters of the theoretical and application fields, formed the structure of the lower branches and extended its place in the scientific circulation parallel to current medicine and technology in an inter / multi disciplinary plane with independent scientific framework. In addition to basic medical sciences and primary medical applications, oral treatment and oral surgery draws the boundaries of the curriculum of the dentistry sciences (1).

The aim of the medical and dental training which are given in the curriculum is to provide students with the basic knowledge and skills of their profession (2). The human anatomy, the oldest known medical science, is described as one of the most important components of medical and dental education (3). The anatomy is broadly defined as the science of studying the normal shape, and structure of organs, the location of these organs, and the structural and functional relationships between them in the broad sense (4). Anatomy is a discipline given to the students of medicine, dentistry and health sciences in the first years of their education and it is the basis for medical terminology and clinical sciences (5). Anatomy as a visual science has a very important place in the curricula of basic medical sciences of medical faculties (5).

Anatomy education is given in the form of theoretical and practical courses in the faculties of Medicine and Dentistry and mainly include cadaver-based practices. Since dissections provide the ability to recognize the three-dimensional structure of the body which cannot be obtained by methods such as books, Atlas, model, computer programs, practical courses in anatomy education are as important as theoretical courses (6).

There are various published researches on the anatomy education in dentistry in the literature $(7,8)$. These studies have been discussed more and helped to further the education of a scientific axis anatomy Surveys reveal the tendency of dissection based on anatomy education approach to leave its place in projection and computer based on modeling in recent years (9). The first study on student feedback, one of the most frequently used methods to assess educational effectiveness since the early 1900's, was conducted at Purdue University in 1927 (10). In addition to its role in overwhelming the difficulties due to changes in the curriculum and contributing to communication between students and lectureres, feedback from the students, it is an important and integral component of the teaching process and students' knowledge and it increaeses professional success $(11,12)$. The so-called student appreciation, satisfaction or feedback is the most frequently used method in evaluating education in higher education (13-15).

In a crowded group of student teams consisting of 5-7 students, the learning based on team work actively participated by the learners is carried out by a team of specialists in place of individuals and teams in order to realize individual and team level learning, can be defined as a teaching strategy (15). According to Vygotsky's (1978) (16) theory of social constructivism, learners' sense of meaning and meaning are realized through social interactions. Teachers and other students have a fundamental role in understanding social interaction knowledge. The cognitive skills that can be developed with expert guidance and co-operation with peers always involve a larger area that can be developed alone, that is, better and more learning is possible with social interaction. Since educational programs are dynamic processes, it is important to monitor them with feedback and to use interactive methods in education (17).

There is a widespread anatomy satisfaction survey in medical faculties and there is no study evaluating the anatomy training of dental students as a whole. Anatomy education between Europe and Turkey was compared, but no concrete information was obtained because questions about the quality of education and its development were not asked. In this study, we aim to reveal the effects of dental faculty students' anatomical thinking about their anatomy and their education interactively with team work and their effects on anatomy learning, and to emphasize the importance of anatomy education in dental faculties and thus to reach more concrete information

\section{Material-Method}

Students who participated in the study signed an approval form for survey. In this study, first-year students who took Anatomy course at Faculty of Dentistry in the spring semester of 2016-2017 academic years were taken as population. No attempt was made to select a sample, and the entire population was tried to be reached. 60 persons $(n=60)$ (98.36\%) participated in the study and 1 students (1.63\%) did not participate in the study. In order to allow students to evaluate all the anatomy training they have received, studies were carried out before the final exam after the completion of the courses.

In this cross-sectional, descriptive study, students' opinions about anatomy education were determined using a volunteerbased questionnaire. In which 29 closed-ended questions were asked to the students. The questionnaire form consists of demographical information, course materials and grades of students, and their thoughts about anatomy education. The items about satisfaction were designed as a 5-point Likerttype scale consisting of "always", "mostly", "frequently", "occasional", "never" was used.

During the semester, practical project assignments were given in order to provide interactive participation of the students in the classroom and to facilitate their anatomy learning. For project assignments, students are asked to form a total of 10 teams consisting of 6 people. The teams were asked to randomly share anatomical systems in accordance with the curriculum of the general anatomy they had taken by the lecturer, and they were asked to plan and implement an applied project on the topics. The project content includes 
the presentation of posters, three-dimensional materials, preparing a power point presentation, and a presentation of the work they do on each team topic (Figure1).

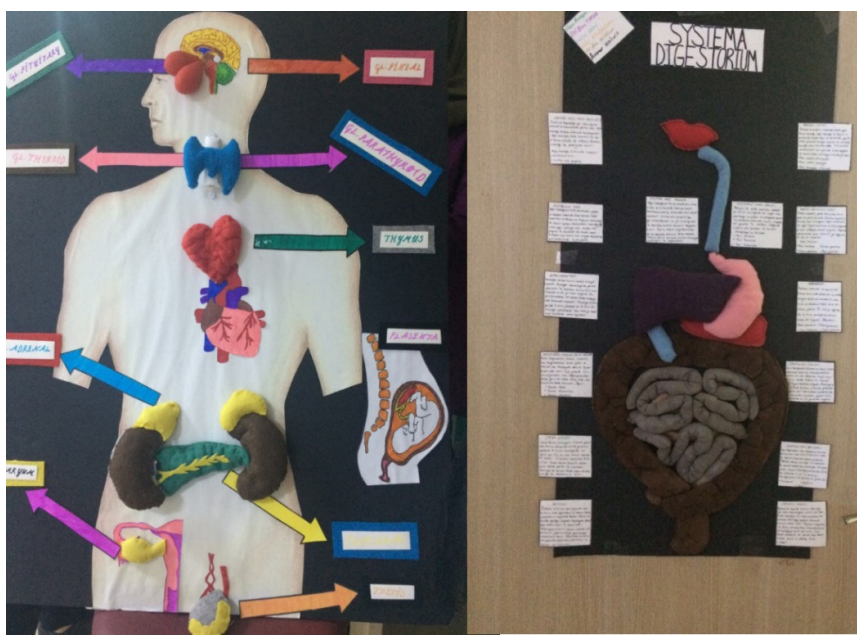

Figure 1. Endocrine and digestive system poster presentations

In the survey used in the study, six questions were asked in the "very little", "little", "medium", "excess", "too many" options in order to evaluate the contributions of the teams to their anatomy learning. The name, surname and student numbers of the students were not included in the questionnaire which was used to make the feedback reliable. During the implementation of the questionnaires, it was tried to ensure that no one of the teaching staff of the Department of Anatomy was present.

Statistical analyses were performed using IBM SPSS version 20 for Windows. Categorical variables were compared using the Chi-square test and were expressed as counts and percentages. The Kruskal- Wallis H test was used to compare the grups of resources that the practitional and the theoretical part of the anatomy used while working. As a result of these analyses, the groups which were found significant were compared using the Dunn's multiple comparison tests. The results of numeric variables were presented as mean \pm standard deviation and median. $\mathrm{P}<0.05$ was considered statistically significant.

\section{Results}

The mean age of 60 students participating in the study was $19.65 \pm 1.31(\mathrm{~min}=18-\mathrm{max}=24)$. Of these students, $33(55.0 \%)$ were female and $27(45.0 \%)$ were male $(p>0.05)$. The average grade score of the students was $54.05 \pm 18.63$ ( $\mathrm{min}=10.00$ $\max =90.00$ ) and the final grade was $71.81 \pm 12.40$. It was determined that $49(81.7 \%)$ of the students liked the theoretical lessons, $11(18.3 \%)$ did not like it, 39 (65.0\%) liked the practical lessons and $21(35.0 \%)$ did not. The demographic characteristics of the students participating in the study, their attendance at the classes, and the duration of the anatomy are shown in Table 1.

The answers of the students' opinions about the anatomy education, the opinions of the teachers about the method and style of teaching the lectures, the adequacy levels of the
Table 1. Demographic characteristics of students, visa grade averages, attendance to classes and anatomy working times

\begin{tabular}{llll}
\hline General Information of Students & $\mathbf{n}$ & $\mathbf{\%}$ & $\mathbf{P}$ \\
\cline { 1 - 3 } What is your gender? & & & \\
\cline { 1 - 3 } Famele & 33 & 55.0 & 0.439 \\
Male & 27 & 45.0 & \\
\hline
\end{tabular}

\begin{tabular}{llll}
\hline $\begin{array}{l}\text { Did you enjoy your dentist's } \\
\text { department? }\end{array}$ & & \\
\cline { 1 - 3 } Yes & 44 & 73.3 & \\
No & 16 & 26.001
\end{tabular}

Are you happy in the dental depart-

ment at this moment?

\begin{tabular}{|c|c|c|}
\hline Yes & 53 & 88.3 \\
\hline No & 7 & 11.7 \\
\hline
\end{tabular}

What is your continuation to

anatomy theoretical courses?

\begin{tabular}{|c|c|c|}
\hline Continuous & 53 & 88.3 \\
\hline I have problems going on & 7 & 11.7 \\
\hline
\end{tabular}

\begin{tabular}{|c|c|c|}
\hline $\begin{array}{l}\text { What is your continuation to } \\
\text { anatomy practice courses? }\end{array}$ & & \\
\hline Continuous & 52 & 86.7 \\
\hline I have problems going on & 8 & 13.3 \\
\hline
\end{tabular}

How many hours a week do you work anatomy individually?

\begin{tabular}{llll}
$0-1$ hour & 18 & 30.0 & 0.015 \\
$1-3$ hour & 23 & 38.3 & \\
$3-5$ hour & 13 & 21.7 & \\
\cline { 1 - 2 } & & &
\end{tabular}

education materials presented to the students, the thoughts about the examinations made and the teachers' communication levels are shown in Table 2.

Students were asked to sort out the resources they used for the theoretical and practical parts of the anatomy most recently. For theoretical and practical lectures of anatomy, four basic educational materials were ordered from the most to the least used. The students made this sequence by giving numerical values from 1 to 4 (most preferred 4, least preferred 1) for the training materials they used. For statistical calculations of the data, the maximum values of the range of values (maximum for the theoretical and practical part $=4$ ) were given for the most preferred training material. For the least preferred training material, the minimum value of the range of values $1(\min =1)$ was given. Thus, an average, standard deviation, median and $p$ value was obtained for each training material used in the theoretical and practical part of the anatomy. The average of these values was the largest, the most educational material the students used, and, the least educational material they used. According to this data, the most useful source of the students' theoretical part of the anatomy was lecture notes with $2.66 \pm 1.39$. Course notes were followed by atlas (printed book) with $2.55 \pm 0.83$, atlas (interactive / pdf) with $2.33 \pm 0.93$, 
Table 2. Evaluation of students' thoughts on anatomy education

\begin{tabular}{|c|c|c|c|c|c|c|}
\hline Students' thoughts on anatomy education & $\begin{array}{c}\text { Always } \\
\text { n (\%) }\end{array}$ & $\begin{array}{c}\text { Mostly } \\
\text { n (\%) }\end{array}$ & $\begin{array}{l}\text { Often } \\
\text { n (\%) }\end{array}$ & $\begin{array}{c}\text { Sometimes } \\
\text { n (\%) }\end{array}$ & $\begin{array}{c}\text { Never } \\
\text { n (\%) }\end{array}$ & $\mathbf{P}$ \\
\hline Do you enjoy working with anatomy? & $3(5.0)$ & $13(21.7)$ & $8(13.3)$ & $30(50)$ & $6(10)$ & $<0.001$ \\
\hline $\begin{array}{l}\text { Do you think that the theoretical training of anatomy } \\
\text { is sufficient in your faculty? }\end{array}$ & $21(35.0)$ & $23(38.3)$ & $9(15.0)$ & $7(11.7)$ & $0(0.0)$ & 0.004 \\
\hline $\begin{array}{l}\text { Do you think that the practical training of anatomy } \\
\text { is sufficient in your faculty? }\end{array}$ & $18(30)$ & $19(31.7)$ & $14(23.3)$ & $7(11.7)$ & $2(3.3)$ & 0.001 \\
\hline $\begin{array}{l}\text { Do you think that the teaching method of the teacher } \\
\text { affects your success in anatomy in anatomy theory } \\
\text { course? }\end{array}$ & $23(38.3)$ & $17(28.3)$ & $10(16.7)$ & $10(16.7)$ & $0(0.0)$ & 0.049 \\
\hline Do you find the number of mannequins enough? & $10(16.7)$ & $20(33.3)$ & $8(13.3)$ & $19(31.7)$ & $3(5.0)$ & 0.001 \\
\hline $\begin{array}{l}\text { Do you think that the anatomical theoretical } \\
\text { examinations made in your faculty assess and } \\
\text { evaluate your anatomic knowledge adequately? }\end{array}$ & $15(25.0)$ & $22(36.7)$ & $8(13.3)$ & $10(16.7)$ & $5(8.3)$ & 0.005 \\
\hline $\begin{array}{l}\text { Do you think that your anatomy practice exams in } \\
\text { your faculty measure and evaluate your anatomy } \\
\text { knowledge adequately? }\end{array}$ & $16(26.7)$ & $16(26.7)$ & $12(20.0)$ & $9(15.0)$ & $7(11.7)$ & 0.240 \\
\hline $\begin{array}{l}\text { Can you ask questions easily in the theoretical } \\
\text { lessons? }\end{array}$ & $39(65.0)$ & $12(20.0)$ & $3(5.0)$ & $5(8.3)$ & $1(1.7)$ & $<0.001$ \\
\hline $\begin{array}{l}\text { Can you ask questions easily in the practical les- } \\
\text { sons? }\end{array}$ & $33(55.0)$ & $17(28.3)$ & $5(8.3)$ & $4(6.7)$ & 1(1.7) & $<0.001$ \\
\hline
\end{tabular}

Table 3. Descriptive statistics of the sources that students use the practical and theoretical part of the anatomy

\begin{tabular}{|c|c|c|c|c|}
\hline & Resources & Mean \pm SD & Median & $\underset{\mathbf{K W}}{\mathbf{P}}$ \\
\hline \multirow{4}{*}{$\begin{array}{l}\text { When you use the theoretical part of the anatomy, } \\
\text { what resources do you use the most, the most } \\
\text { aesthetically correct one? }\end{array}$} & Lecture Notes (I) & $2.66 \pm 1.39$ & 3 & \multirow{4}{*}{0.225} \\
\hline & Atlas (printed book) (II) & $2.55 \pm 0.83$ & 3 & \\
\hline & Atlas (interactive / pdf) (III) & $2.33 \pm 0.93$ & 2 & \\
\hline & Textbook(IV) & $2.18 \pm 1.42$ & 2 & \\
\hline \multirow{4}{*}{$\begin{array}{l}\text { When you use the practical part of the anatomy, } \\
\text { what resources do you use the most, the most } \\
\text { aesthetically correct one? }\end{array}$} & Lecture Notes (I) & $2.26 \pm 0.95$ & 2 & \multirow{4}{*}{0.05} \\
\hline & Atlas (printed book) (II) & $2.32 \pm 1.16$ & 2 & \\
\hline & Atlas (interactive / pdf) (III) & $2.50 \pm 0.89$ & 3 & \\
\hline & Textbook(IV) & $2.95 \pm 1.32$ & 4 & \\
\hline
\end{tabular}

Table 4. Evaluation of students' thoughts about project assignments given in anatomy class

\begin{tabular}{|c|c|c|c|c|c|c|}
\hline $\begin{array}{l}\text { Students' thoughts on anatomical project } \\
\text { assignments }\end{array}$ & $\begin{array}{l}\text { Very little } \\
\text { n }(\%)\end{array}$ & $\begin{array}{l}\text { Little } \\
\text { n (\%) }\end{array}$ & $\begin{array}{l}\text { Middle } \\
\text { n (\%) }\end{array}$ & $\begin{array}{l}\text { Much } \\
\text { n (\%) }\end{array}$ & $\begin{array}{l}\text { Too Much } \\
\text { n (\%) }\end{array}$ & $\mathbf{P}$ \\
\hline $\begin{array}{l}\text { How much contribution did homework make to } \\
\text { learning that anatomy? }\end{array}$ & $1(1.7)$ & $4(6.7)$ & $21(35.0)$ & $27(45.0)$ & $7(11.7)$ & $<0.001$ \\
\hline $\begin{array}{l}\text { How much did your homework anatomy contribute } \\
\text { to your anatomy before you prepared your } \\
\text { homework? }\end{array}$ & $6(10.0)$ & $12(20.0)$ & $23(38.3)$ & $15(25.0)$ & $4(6.7)$ & 0.001 \\
\hline $\begin{array}{l}\text { How much did your homework "broke an anatomy } \\
\text { prejudice"? }\end{array}$ & $10(16.7)$ & $10(16.7)$ & $24(40)$ & $13(21.7)$ & $3(5.0)$ & 0.001 \\
\hline $\begin{array}{l}\text { What is the contribution of the General Anatomy } \\
\text { course you took this term to your education? }\end{array}$ & $0(0.0)$ & $4(6.7)$ & $16(26.7)$ & $24(40.0)$ & $16(26.7)$ & 0.004 \\
\hline $\begin{array}{l}\text { Do you think that the lack of cadaver in anatomy } \\
\text { training is a deficiency in the anatomy learning } \\
\text { process? }\end{array}$ & $8(13.3)$ & $7(11.7)$ & $17(28.3)$ & $13(21.7)$ & $15(25.0)$ & 0.176 \\
\hline
\end{tabular}


source that the students used for the practical part was $2.95 \pm 1.32$ for course book, $2.50 \pm 0.89$ for Atlas (interactive / PDF), $2.3 \pm 1.16$ for Atlas (printed book), and 2.26 \pm 0.95 for course notes (Table 3 ).

The statistical analysis of the students' contribution to learning the anatomy of the relevant subject, the contribution they make to the anatomy, prejudices about the anatomy, contributions to the training of the "General Anatomy" course during the semester and answers to the questions about lack of cadaver lack in anatomy trainings are given in Table 4.

\section{Discussion}

Student feedback is one of the most commonly used methods of assessing educational effectiveness since the early 1900's (18). Reliability and validity studies are required to reflect the true state of the data obtained from student feedback forms (19). The student feedback provided by the questionnaire is one of many evaluation methods showing the quality of the education offered to them and reliability and validity are high (20). In this context, it is very important to evaluate the feedback obtained from the questionnaire studies applied to the students and to reflect the results to the education and training process in the following years. Regular evaluation of the trainings provided by the students will greatly contribute to the improvement of the quality of education offered to them, to the elimination of the identified deficiencies and to the development of new training strategies that will contribute to them. Therefore, feedback from students is very important in achieving the goals of anatomy education.

Anatomy information is very important in the realization of the physical examination of the patient in medicine and dentistry, in making the right diagnosis for the complaints and in sharing the obtained findings with patients and health personel (21). Therefore, good anatomy training is needed in order to educate qualified physicians, to give the right diagnosis for the symptoms as soon as possible, to determine the most appropriate surgical intervention if necessary and to apply it in the most correct way. For this reason, there are studies in the literature evaluating the opinions of students about their anatomy education.

It was found that $22.9 \%$ of the students in term I and $78.1 \%$ of the students in term II were positive about the anatomical theoretical courses in the study conducted in the students of term I and term II of Akdeniz University Medical Faculty (20). $61.7 \%$ of 2 nd grade students of Gazi University Faculty of Medicine stated that they were generally satisfied with the theoretical courses of the anatomy and $72.2 \%$ with the anatomy practice courses (17). Tuygar et al. (22) conducted studies at four different medical faculties and found that students' satisfaction with theoretical and practical training of anatomy was moderate (3.32 and 3.33, respectively, over 5). In the study conducted at Gaziantep University, the satisfaction level of the students with the theoretical and practical part of the anatomy education was determined as $67.4 \%$ and $55 \%$ respectively (23). In this study conducted in the Faculty of Dentistry, $88.3 \%$ of the theoretical part of the anatomy and $85.0 \%$ of the practical part were obtained and satisfaction levels were determined in the anatomy training they received. In the study conducted by Gözil et al. (17) reported that, for medical faculty students, $83.3 \%$ of the students found delivery of lecture notes useful in learning. It is seen that study notes prepared by Çetkin et al. (23) for the medical faculty students are the most frequently used educational material. Similare to the literature, it was found that the most frequently used educational material in theoretical courses was course notes. According to this data, the teachers of anatomy should consider that this training material is frequently used for students and it contributes to learning the lesson.

In the study conducted by Sindel et al. (11) $49.6 \%$ for first year students and $78.1 \%$ for second year students thought that the effect of the lectures on the understanding is high. In study conducted by Gözil et al. (17) $58.9 \%$ of the students stated that the way of teaching facilitated their learning. In Çetkin et al.'s study (23), 91.7\% of the students stated that the teacher's anatomical success in the teaching of anatomy was influenced by the teaching method. In our study, $83.3 \%$ of the students stated that the anatomical success of the lecturer's teaching method in anatomy theoretical courses was affected. The results we obtained are similar to the literature.

Another important consequence of the study is; related project assignments given to students. Regarding the project assignments given, $71.7 \%$ of the students completed their homework within $1-3$ weeks, $70.0 \%$ of them gave their anatomical likes, $91.7 \%$ of them contributed to learning the anatomy of that subject, and $73.4 \%$ of them had broken the prejudice of "anatomy working and understanding is difficult".

We anticipate that the data obtained as a result of this study will direct the anatomy trainings to be presented to the students in the following years and that the interactive educators will be more helpful to learn the lesson. We also think that the time and effort spent for anatomy training, in medical faculties, are also very important in dentistry faculties.

\section{Acknowledgements}

Adiyaman University Faculty of Dentistry thank for their contribution to first-year students.

This study datas were presented as oral presentation at the 18th National Anatomy Congress.

\section{References}

1. Pamay A, Büyükertan M, Balcığlu HA. Avrupa ve Kuzey Amerika ülkelerindeki diş hekimliği fakültelerinde anatomi eğitimine dair karşılaştırmalı bir inceleme. Yeditepe J Dent 2107; 13(2): 29-33.

2. Gürpınar MA, Gürpınar E, Songur A, Vitrinel A. Mezuniyet öncesi tıp eğitimi ulusal çekirdek eğitim programı-2014/ Ulusal ÇEP-2014

3. Mclachlan JC, Patten D. Anatomy teaching: Ghost of the post, present and future. Med Educ 2006; 40(3): 243-53.

4. Arifoğlu Y, editörler. Her Yönüyle Anatomi. İstanbul. İstanbul Tıp Kitabevi 2017; s.15. 
5. Singh R, Tubbs RS, Gupta K, Singh M, Jones DG, Kumar $\mathrm{R}$. Is the decline of human anatomy hazardous to medical education/ profession?-A review. Surg Radiol Anat 2015; 37 : 1257-65.

6. Gürpınar E, Batı H, Tetik C. Tıp fakültesi öğrencilerinin öğrenme stillerinin belirlenmesi. Tıp Eğitimi Dünyası 2011; 32: $18-29$.

7. Balcığlu HA, Kotken G, Guven Y. Future Perspectives of Anatomy In Dental Education: Quo Vadis? Int J Morphol. 2010; 28: 71-73.

8. Lazarius MD, Chınchıllı VM, Leong SL, Kaufman GL Jr. Perspections of anatomy: Critical components in the clinical setting. Anatomical sciences education 2012; 5: 187-199.

9. Vuchkova J, Maybury T, Farah SC. The Educational Value of Online Mastery Quizzes in a Human Anatomy Course for Digital İnteractive learning of oral radiographic anatomy. Eur J Dent Educ 2012; 16: 79-87.

10. Karabilgin ÖS, Şahin H. Eğitim etkinliğini değerlendirmede öğrenci geri bildiriminin kullanımı. Tıp Eğitimi Dünyası 2006; 21: 27-33.

11. Sindel M, Şenol Y, Gürpınar E. Akdeniz Üniversitesi Tıp Fakültesinde anatomi eğitiminin öğrenciler tarafından değerlendirilmesi. Tıp Eğitimi Dünyası 2008; 28: 31-6.

12. Schartel SA. Giving feedback-an integral part of education. Best Pract Res Clin Anaesthesiol 2012; 26: 77-87.

13. Fresko B, Nasser F.Interpreting Student Ratings: Consultation, Instructional Modification, and Attitudes Towards Course Evaluation, Studies in Educational Evaluation 2001; 27: 291-305.

14. Wankat PC, Oreovicz FS. William G. Gray. Teaching Engineering. USA. Purdue University Press 2015; p. 378405.
15. Fink LD. Beyond Small Groups: Harnessing the Extraordinary Power of Learning Teams. In: Michaelsen LK, Knight AB, Fink LD, eds. Team-Based Learning: A Transformative Use of Small Groups. 1.Bask1. Westport, Connecticut and London: Praeger; 2002.

16. Vygotsky LS. Educational Implications. Michael Cole. Mind in Society: The Development of Higher Psychological Processe. Cambridge. MA: Harvard University Press 1978; p.79-91.

17. Gözil R, Özkan S, Bahçelioğlu M, Kadıoglu D, Çalgüner E, Öktem H. Gazi Üniversitesi Tıp Fakültesi 2.sınıf öğrencilerinin anatomi eğitimini değerlendirmeleri. Tip Eğitimi Dünyası 2006; 23: 27-32.

18. Karabilgin ÖS, Şahin H. Eğitim etkinliğini değerlendirmede öğrenci geri bildiriminin kullanımı. Tıp Eğitimi Dünyası 2006; 21: 27-33.

19. Arreola R.A. Time table for developing a comprehensive faculty evalation system. Wiley. Developing a Comprehensive Faculty Evaluation System. Bolton MA. Second Edition, Anker Publishing Company 2000; p. 95.

20. Penny AR. Changing the agenda for research into students' views about university teaching: four shortcomings of SRT research. Teach in High Educ 2003; 8: 399-411.

21. Turney BW. Anatomy in a modern medical curriculum. Ann R Coll of Surg Engl 2007; 89: 104-7.

22. Tuygar F, Kuş İ, Saygılı AK, Özcan E, Gülcen B. Tıp fakültesi öğrencilerinin anatomi eğitimine yönelik memnuniyet düzeyleri ve ilgili değişkenlerin incelenmesi. Tıp Eğitimi Dünyası 2015; 42: 5-14.

23. Çetkin M, Turhan B, Bahşi İ, Kervancıoğlu P. Tıp fakültesi öğrencilerinin anatomi eğitimi hakkındaki düşünceleri. Gaziantep Medical Journal 2016; (2): 82-88. 